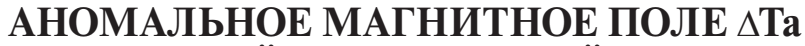 ЭКВАТОРИАЛЬНОЙ ЧАСТИ ИНДИЙСКОГО ОКЕАНА (СЪЕМКА НА ПОЛИГОНАХ)
}

\author{
(C) 2020 И.А. Веклич, А.Н. Иваненко, О.В. Левченко
}

\begin{abstract}
Институт океанологии им. П.П. Ширшова РАН, Москва, Россия; e-mail: veklich.ilya11@mail.ru
\end{abstract}
\begin{abstract}
В 42 рейсе НИС «Академик Борис Петров» (2017 г.) после длительного перерыва Институтом океанологии им. П.П. Ширшова РАН возобновлены натурные геофизические исследования в Индийском океане. Наряду с батиметрической и сейсмоакустической съемками в рейсе отснято более 10000 км профилей модульной гидромагнитной съемки. Основные работы выполнены в экваториальной восточной части Индийского океана - северном сегменте Восточно-Индийского хребта и зоне внутриплитных деформаций в Центральной котловине. Разработаны специальные алгоритмы для интерпретации магнитных аномалий в низких широтах. На полигонах выделен ряд локальных интенсивных магнитных аномалий, для которых подобраны эквивалентные модели источников, характеризующие связанные с ними геологические объекты. Оценки палеоширот для ряда объектов в северной части Восточно-Индийского хребта указывают на возможное развитие здесь наложенных вулкано-магматических процессов, не связанных напрямую с магматизмом горячей точки Кергелен. Для зоны внутриплитных деформаций установлено, что магнитоактивный слой продолжается намного глубже пределов стандартной модели магнитоактивного слоя океанической литосферы, а исследованные источники, вероятно, связаны с застывшими магматическими камерами, сформированными на флангах спредингового хребта.
\end{abstract}

Ключевые слова: Индийский океан, аномальное магнитное поле, тектоника, внутриплитная деформация.

\section{ВВЕДЕНИЕ}

Сложная геологическая история Индийского океана запечатлена в пестром и неоднородном рисунке магнитных аномалий, однозначная расшифровка которого сталкивается с определенными трудностями. Особенно это касается его восточного сектора, уникального по своему формированию (Хаин, 2001), неоднородному тектоническое строению, что проявляется в структуре коры, литосферы и геофизических полей (Булычев и др., 2014) и отражает многоэтапную эволюцию спрединговых центров и мантийных плюмов после раскола Гондваны и закрытия древнего океана Тетис (Royer et al., 1991; Royer, Sandwell, 1989). Тектоника и геодинамика этой части Индийского океана отражает взаимодействие напряжений растяжения в спрединговых хребтах Центрально-Индийском и Юго-Восточно-Индийском и напряжений сжатия на коллизионной гималайской границе Индийской плиты и в Зондской субдукционной границе. Существенное влияние на тектономагматическую эволюцию этого региона оказывал мантийный плюм Кергелен (Сущевская и др., 2016, 2017; Krishna et al., 2012; Royer et al., 1991). В восточном секторе Индийского океана наблюдается множество уникальных геологических структур и феноменов глобального, регионального и локального масштаба. Здесь сформировались разнообразные по генезису большие океанические плато, подводные хребты и отдельные горы, включая множество асейсмичных внутриплитных поднятий, природа которых остается дискуссионной (Хаин, 2001; Royer et al., 1991). Гетерогенные тектонические блоки океанической литосферы в северной части сектора отражают сложную картину внутриплитной деформации океанической литосферы (Казьмин, Левченко, 1987; Intraplate ..., 1998).

Восточно-Индийский хребет (ВИХ) - самое протяженное (более 5000 км) линейное внутриплитное поднятие в Мировом океане, занимает в восточном секторе центральное положение. 
Примыкающие к нему с запада Центральная котловина и с востока котловина Вартон (рис. 1), отличаются разным строением литосферы, структурным планом, полем напряжений и другими геолого-геофизическими характеристиками (Геология ..., 1981; Delescluse, Chamot-Rooke, 2007), поэтому ВИХ относят к зоне тектонического раздела планетарного масштаба, приуроченной к гигантскому разлому (Кашинцев, 2001; Пущаровский, 2011). Было предложено множество гипотез природы ВИХ: структура горстового типа, надвиг Индийской плиты на Австралийскую по зоне трансформного разлома, внедрение габбро и серпентинизированных перидотитов в зоне крупного трансформного разлома, разуплотнение перидотитовых масс и их серпентинизация и другие (Геология ..., 1981; Шрейдер, 2001). Некоторые исследователи по-прежнему связывают образование ВИХ с магматически активным разломом (Артамонов, Золотарев, 2008; Кашинцев, 2001; Delescluse, Chamot-Rooke, 2007). Однако после того, как глубоководным бурением был выявлен четкий возрастной тренд закономерного омоложения хребта в южном направлении, доминирующей является гипотеза «следа горячей точки», согласно которой Восточно-Индийский хребет создан магматизмом плюма Кергелен во время дрейфа над ним

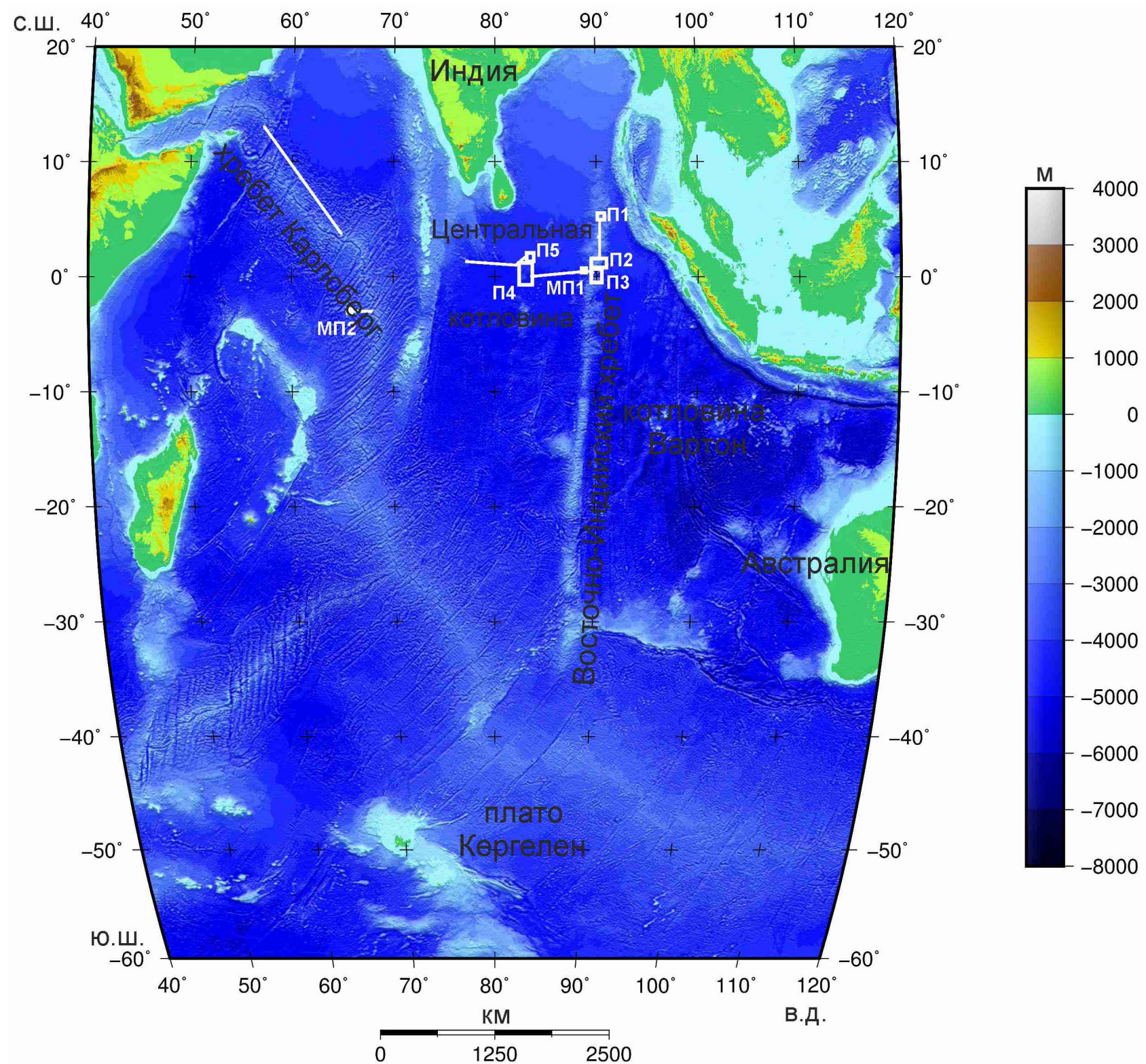

Рис. 1. Схема геомагнитной съемки 42 рейса НИС «Академик Борис Петров» в Индийском океане. Белыми прямоугольниками и линиями выделены границы полигонов и профили геомагнитной съемки, соответственно. Карта построена по данным (GEBCO, 2008).

Fig. 1. Scheme of geomagnetic survey of the $42^{\text {nd }}$ cruise of $R / V$ Academic Boris Petrov in the Indian Ocean. White rectangles and lines show the boundaries of polygons and profiles of geomagnetic survey, respectively. The map was developed according to (GEBCO, 2008). 
Индийской плиты (Krishna et al., 2012; Royer et al., 1991). Высказывалось компромиссное мнение, что часть хребта - это продукт действия плюма, а другая часть сформировалась как трансформный разлом (Royer, Sandwell, 1989). По-видимому, ВИХ является сложно расчлененной блоковой структурой, которая испытала несколько фаз тектонической активности и образована мантийным плюмом Кергелен вблизи крупного трансформного разлома (Левченко и др., 2014; Сущевская и др., 2016; Krishna et al., 2012).

Другим представляющим большой научный интерес объектом в восточном секторе является зона внутриплитной деформации в Центральной котловине южнее Шри-Ланка (рис. 1) (Вержбицкий, Левченко, 2002; Казьмин, Левченко, 1987; Intraplate ..., 1998) В этой зоне наблюдаются интенсивные крупномасштабные молодые ( 8 млн лет, поздний миоцен) складчато-разрывные дислокации осадочного чехла и фундамента, осложненные многочисленными взбросами и складками меньшего порядка. Нарушенные приподнятые тектонические блоки, проявляющиеся также в поле силы тяжести и геоиде (ундуляции литосферы), распределены среди ненарушенных участков дна на севере Центральной котловины (Weissel et al., 1980). Сложная мозаично-блоковая тектоника зоны внутриплитной деформации обусловлена сеткой разломов, которые изначально образовались в процессе спрединга. Зарегистрированные здесь аномально высокий тепловой поток и самая высокая океанская внутриплитная сейсмичность свидетельствуют о сохраняющейся до настоящего времени тектонической активности. Эту деформацию литосферы в интерьере Индо-Австралийской плиты вдали от ее границ большинство исследователей, во многом опираясь на собранные в рейсах фактические данные, объясняет релаксацией напряжения сжатия в теле плиты в результате континентальной коллизии Индостана с Евразией (Казьмин, Левченко, 1987; Intraplate ..., 1998; Weissel et al., 1980 и др.).

После более чем 25-ти летнего перерыва в 2017 г. в 42 рейсе НИС «Академик Борис Петров» были возобновлены геолого-геофизические исследования Института океанологии им. П.П. Ширшова РАН (ИО РАН) в Индийском океане (Левченко, Шаповалов, 2019). Основной задачей этого рейса была комплексная съемка (многолучевая батиметрия, высокоразрешающее сейсмопрофилирование и магнитометрия) северного сегмента внутриплитного асейсмичного Восточно-Индийского хребта и тектонических блоков в зоне внутриплитной деформации индоокеанской литосферы в Центральной котловине. Основными объектами исследования были выбраны подводные горы, для анализа магнитного поля которых ранее были разработаны специальные алгоритмы (Иваненко, 1993). Подводные горы рассматриваются как «окна» в глубину Земли, которые помогают объяснить различные глубинные процессы в литосфере (Iyer et al., 2012; Koppers, Watts, 2010).

Основной целью этой статьи является в первую очередь публикация большого объема новых результатов геомагнитных исследований.

\section{ГЕОМАГНИТНЫЕ ИССЛЕДОВАНИЯ}

Исследования в 42 рейсе НИС «Академик Борис Петров» включали съемку с судовой аппаратурой: батиметрическую с многолучевым эхолотом ATLAS HYDROSWEEP DS-2 (мультибим) и высокоразрешающее сейсмоакустическое профилирование с узколучевым параметрическим профилографом ATLAS PARASOUND DS-2 (парасаунд), а также и гидромагнитную съемку с модульным магнитометром MPMG-4. Съемка проводилась на скорости 9 узлов. В данной статье основное внимание уделено анализу полученных результатов только одного метода - геомагнитной съемки на полигонах. Данные 42-го рейса дополнены данными из международной геофизической базы GEODAS (National ... ) более 3500 миль, и данными рейса НИС «Роджер Ревелл» (2007 г.) (более 670 миль) (Krishna et al., 2012; Левченко и др., 2014).

Основной объем геофизической съемки был выполнен в восточной части Индийского океана (рис. 1): на трех полигонах на северном сегменте ВИХ - П1 (рис. 2), П2 (рис. 3), П3 (рис. 4); двух полигонах в зоне внутриплитных деформаций в Центральной котловине - П4 (рис. 5), П5 (рис. 6); микрополигоне на западном фланге ВИХ - МП1 (рис. 7) (Левченко и др., 2018) и на профилях между ними (рис. 1). Также съемка выполнялась и в западной части Индийского океана, включая микрополигон на подводной горе МП2 (рис. 8) в районе хребта Карлсберг. Для всех полигонов на основании полученных данных построены детальные карты рельефа дна и аномального магнитного поля (АМП) $\Delta$ Та. Все участки полигонных работ объединяет то, что они находятся в экваториальной зоне Индийского океана.

Основная проблема обработки полученных магнитных данных и их геолого-геофизической интерпретации связана с тем, что в экваториальной зоне Индийского океана вектор магнитного поля Земли направлен почти горизонтально. Это затрудняет идентификацию магнитных аномалий от меридионально вытянутых структур типа ВИХ (проекция намагниченности в плоскость сечения поперек структуры близка к нулю). Экстремумы аномалий сильно смещены относительно центров магнитоактивных объектов в 
ВЕКЛИЧ и др.

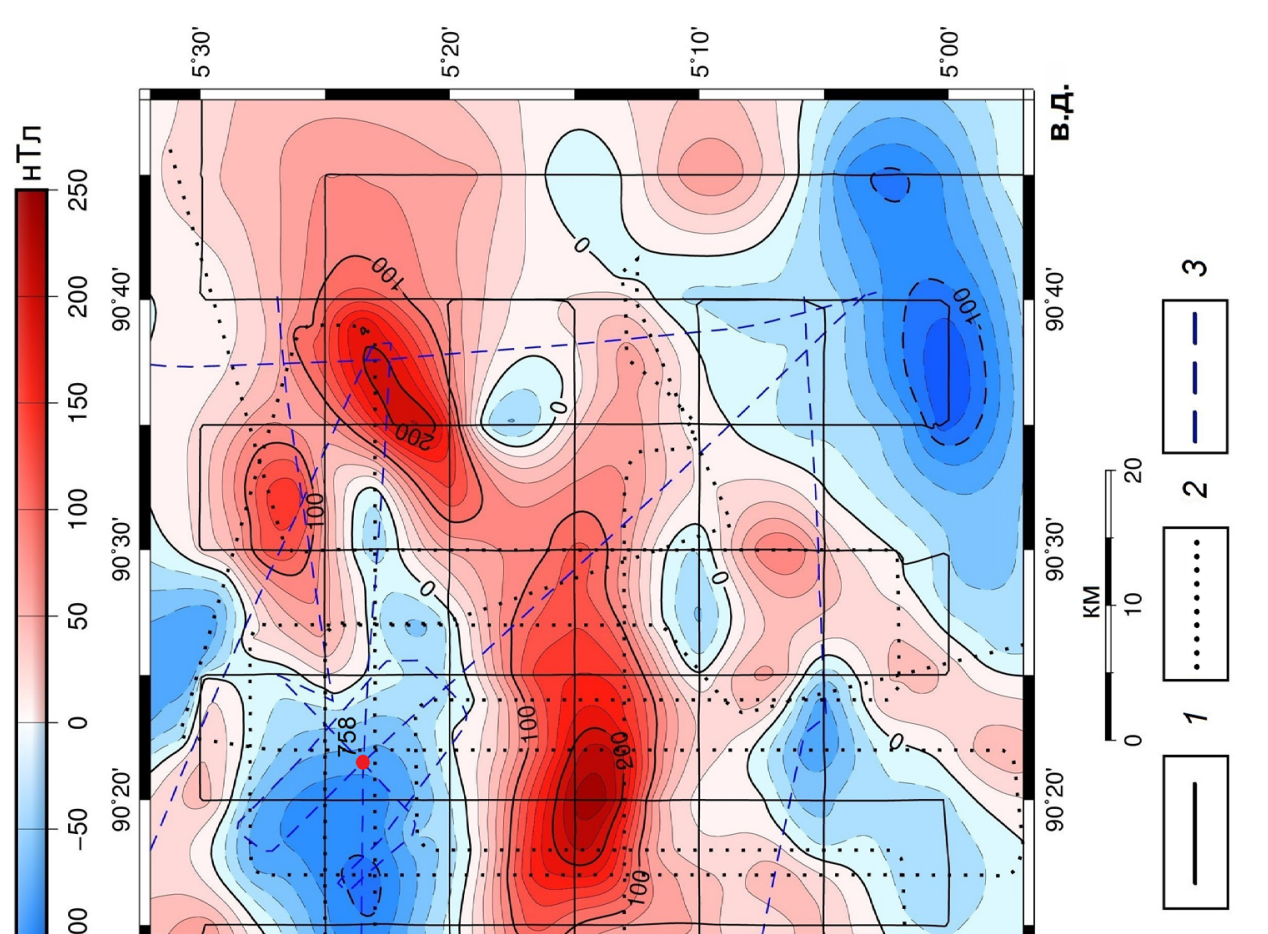

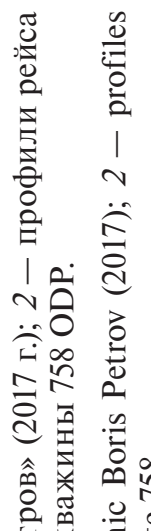

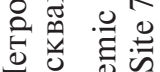

过

웅 $>0$

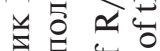

항

式兽兽

这至它

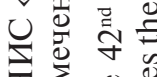

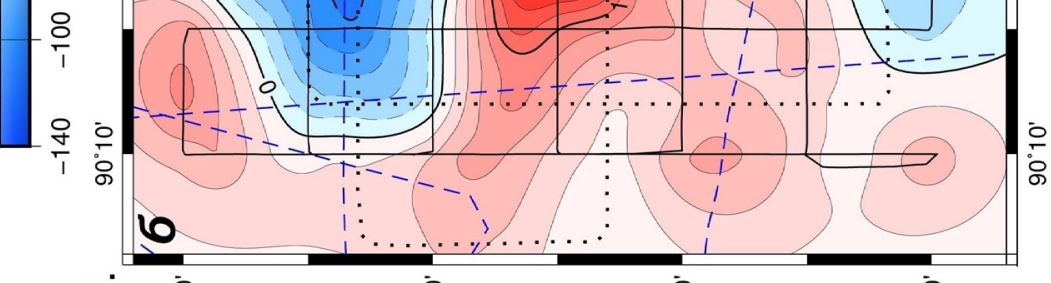

䞍焉

氙

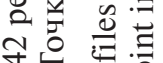

它遂

형 - F

虽望乐

$1 x \approx 0$

ㄱ. 올

秕

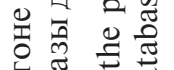

\pm :

응.

폴 흔

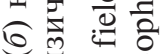

㦴

웡

용

志㺃

预

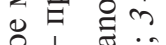

者的苓

을 융

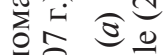

范完

它商

क्ञ

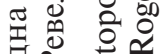

웡

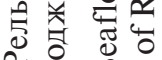

i.

ن 

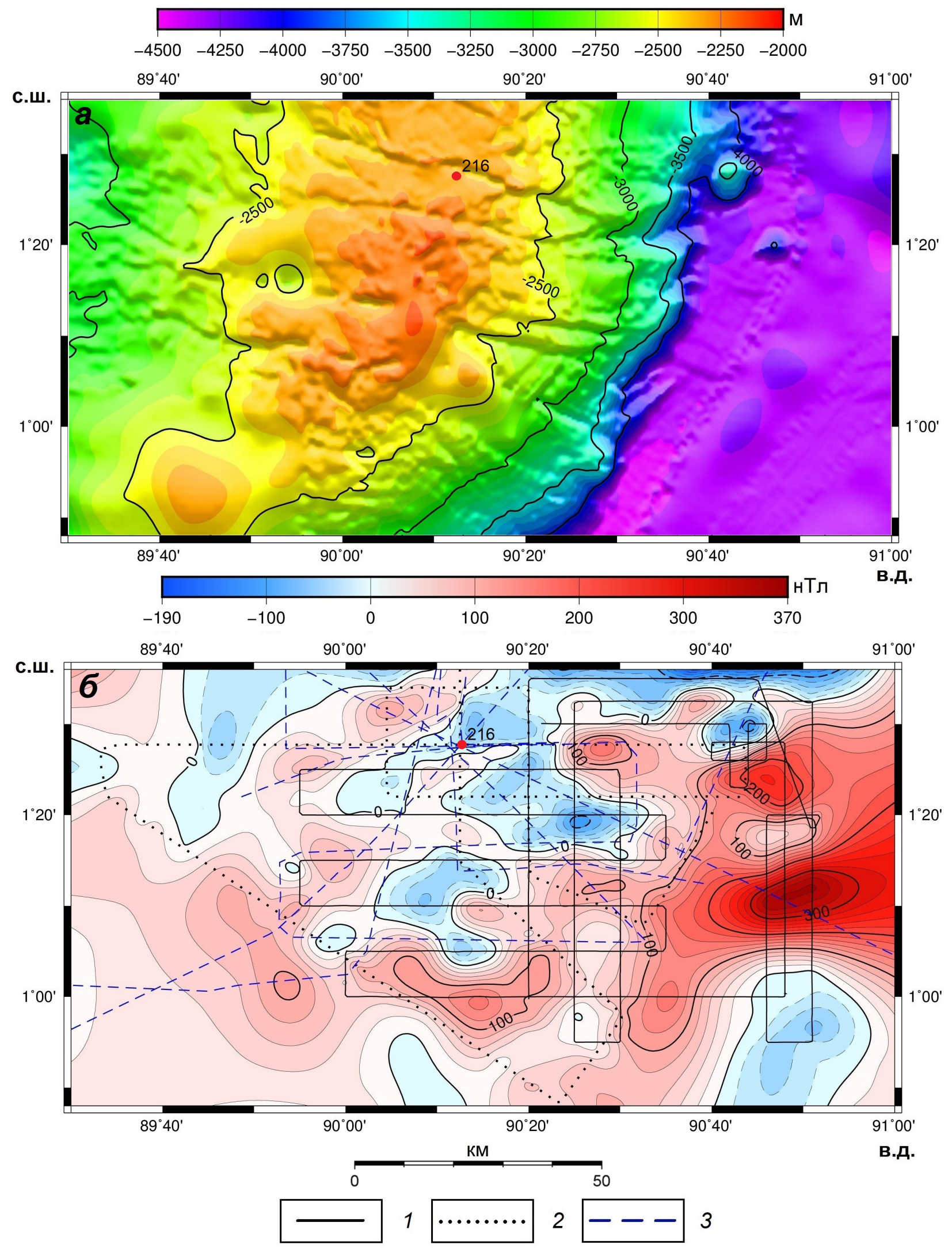

Рис. 3. Рельеф дна (a) и аномальное магнитное поле (б) на полигоне П2: 1 - профили 42 рейса НИС «Академик Борис Петров» (2017 г.); 2 - профили рейса НИС «Роджер Ревелл» (2007 г.); 3 - профили из геофизической базы данных GEODAS. Точкой отмечено местоположение скважины 216 DSDP.

Fig. 3. Seafloor topography $(a)$ and anomalous magnetic field $(\sigma)$ at the polygon P2: 1 - profiles of the $42^{\text {nd }}$ cruise of R/V Academic Boris Petrov (2017); 2 - profiles of cruise of R/V Roger Revelle (2007); 3 - profiles from geophysical database GEODAS. The point indicates the location of the DSDP Site 216. 


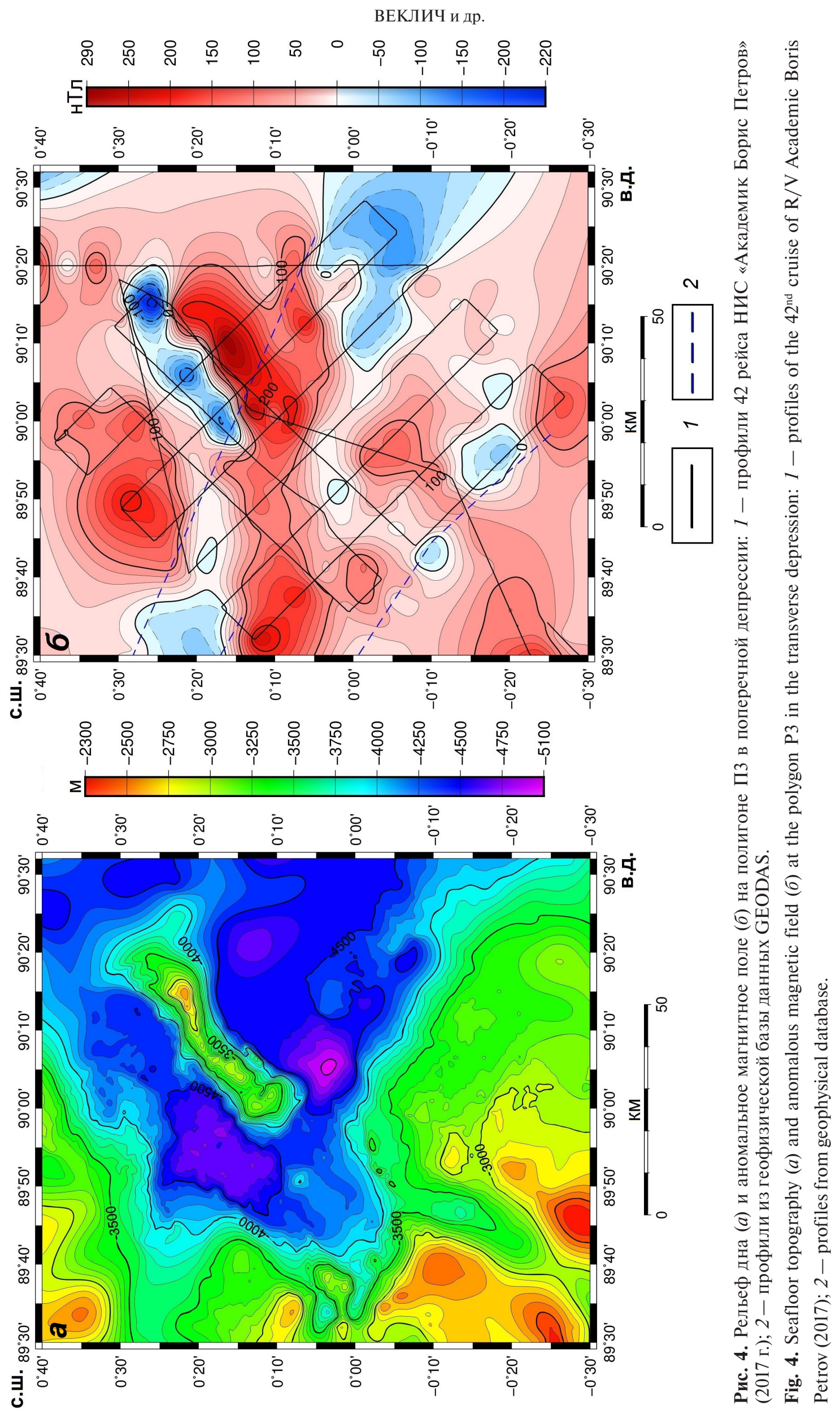


АНОМАЛЬНОЕ МАГНИТНОЕ ПОЛЕ
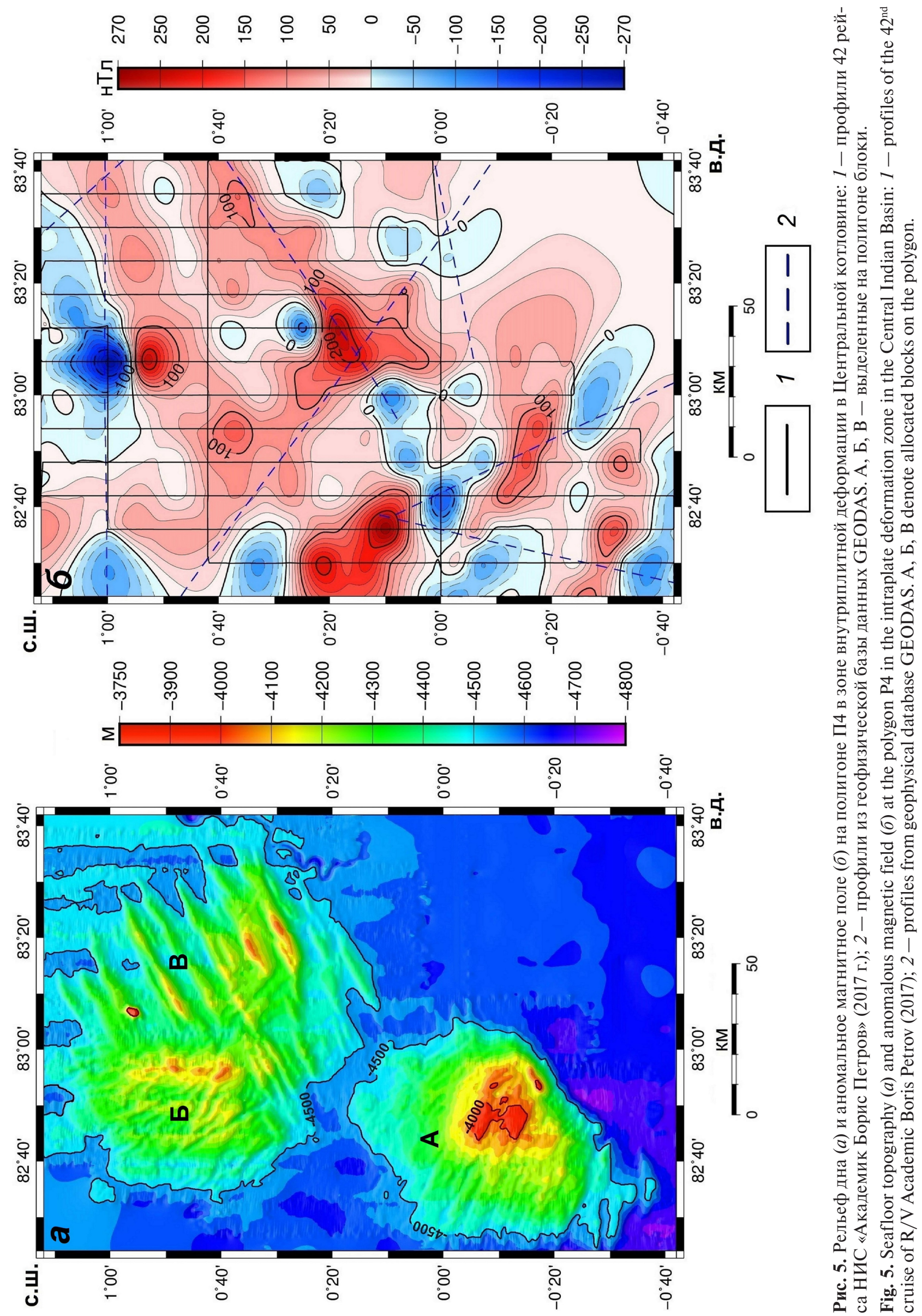
ВЕКЛИЧ и др.

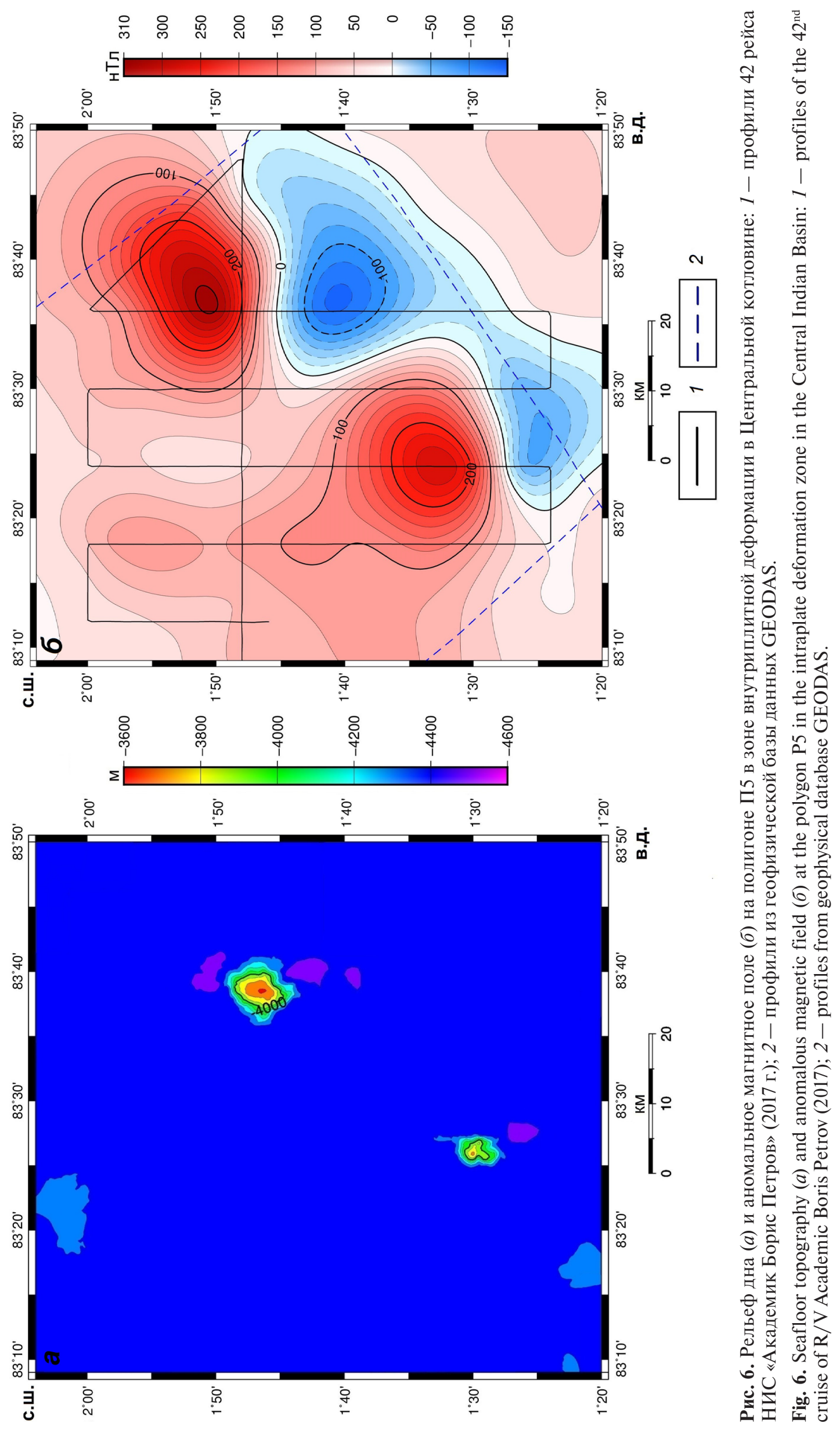




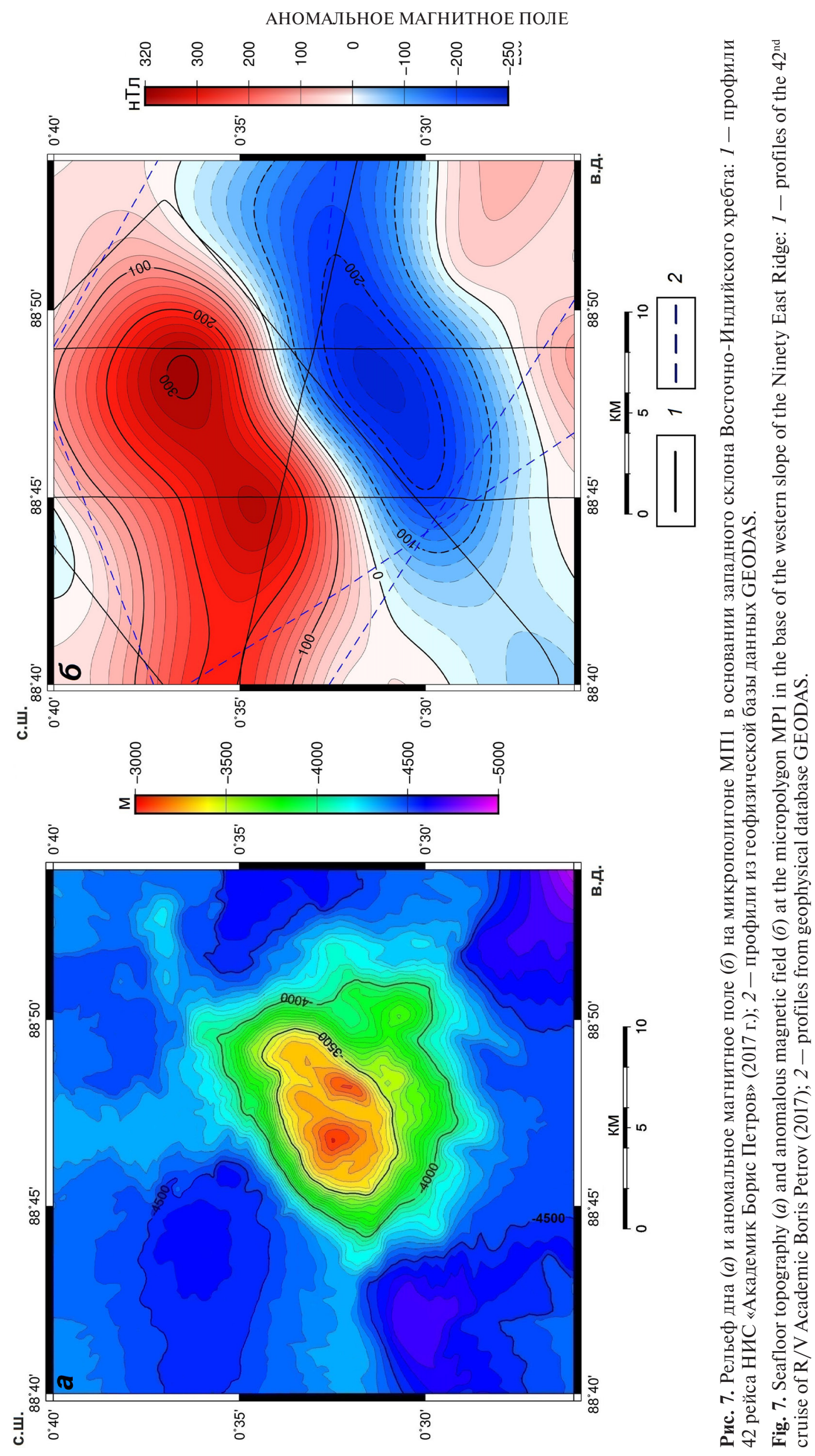




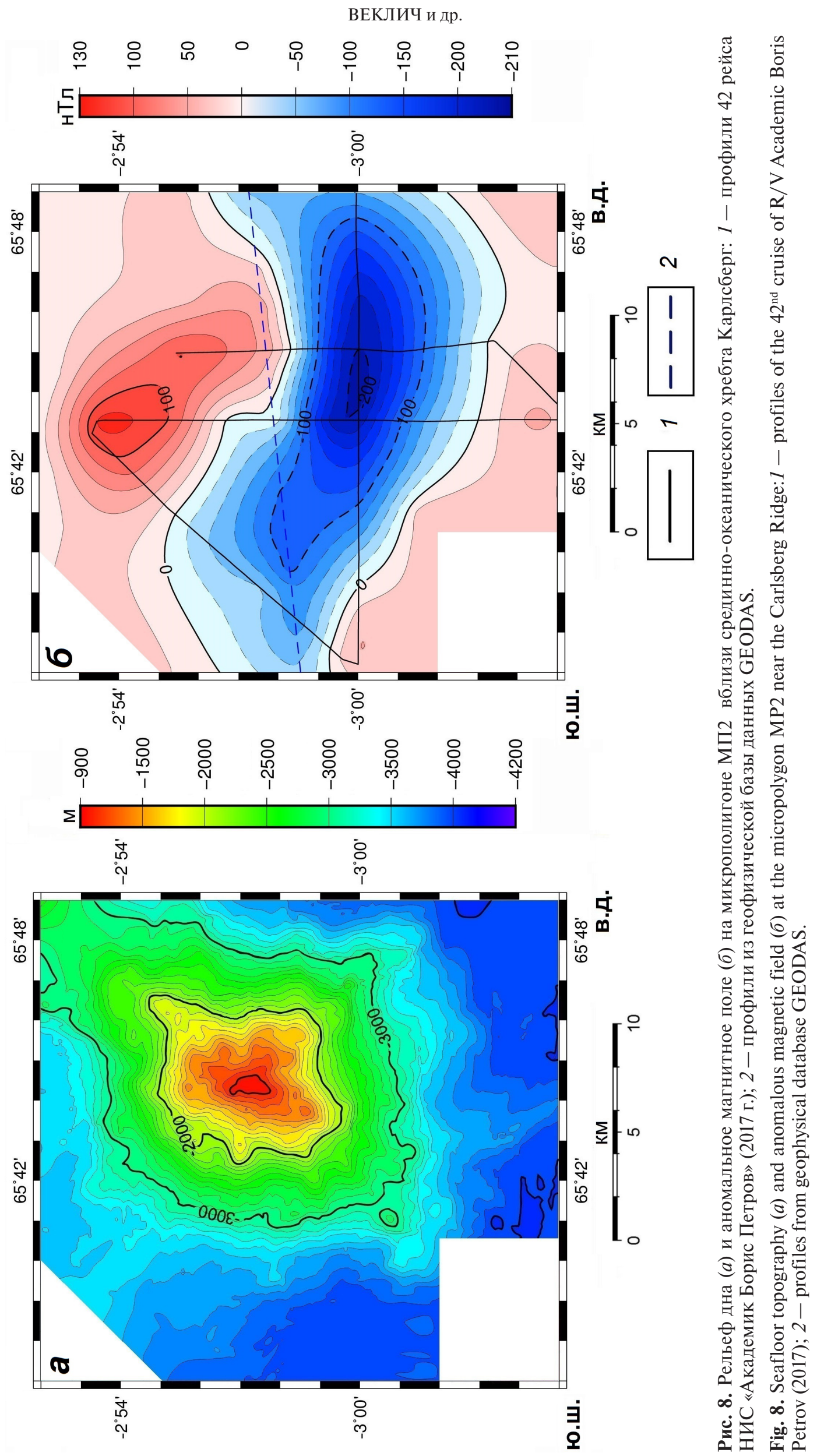


горизонтальной плоскости. Также существуют определенные трудности в приведении аномалий к полюсу, поскольку эта трансформация становится неустойчивой в низких широтах. Профили меридионального направления, наиболее информативные с точки зрения палеомагнитного анализа, расположены вдоль ВИХ и не удовлетворяют условиям применения методов 2D задач. Перечисленные обстоятельства потребовали разработки специальной методики, позволяющей выполнять качественный анализ аномального магнитного поля $\Delta$ Та в экваториальной зоне.

Количественная интерпретация АМП предполагает получение оценок определенного набора геолого-геофизических параметров, характеризующих изучаемую среду. В данном конкретном случае нас интересовало в первую очередь направление эффективной намагниченности магнитоактивных объектов, позволяющее оценивать их палеошироту образования (возраст) и геометрические и петрофизические характеристики объектов (координаты центра магнитных масс и дипольный момент, соответственно), дающие представление о процессах их образования и эволюции. Была разработана специальная методика, позволяющая выполнять устойчивое 3D моделирование магнитных аномалий в низких широтах с акцентированием на перечисленные аспекты. В основу ее положен тот факт, что магнитуда магнитных аномалий является самой малочувствительной к косому намагничению трансформантой аномального поля $\Delta \mathrm{Ta}$ (Gerovska, Arauzo-Bravo, 2006). Поэтому максимумы этой колоколообразной положительной функции отображают центры магнитных объектов практически независимо от направления намагниченности источника и направления внешнего поля. Более того, имея локализованные в плане центры источников аномалий, нам удалось построить чрезвычайно устойчивый алгоритм оценки глубинного положения и магнитного момента эквивалентного дипольного источника. В пределах отработанных в рейсе полигонов было выделено 8 объектов, с интенсивными и четкими (минимально интерферирующими с окружающим полем) локальными магнитными аномалиями (рис. 9). Для изучения их свойств подобраны адекватные модели (рис. 10, таблица).

Необходимо отметить, что при использовании площадных 3D алгоритмов мы столкнулось с проблемой сильных краевых эффектов на концах обрабатываемых полигонов. Поэтому был проведен тщательный отбор данных, оптимальных с точки зрения возможности применения площадных исследований. С этой целью нами были обобщены все доступные гео- магнитные данные, чтобы синтезировать карты аномального магнитного поля, включающие прилегающие к полигонам участки.

Восточно-Индийский хребет. Структурно неоднородный ВИХ состоит из поднятых и опущенных блоков, которые характеризуются различными магнитными аномалиями (Геология ..., 1981; Шрейдер, 2001). К его осевой части приурочены преимущественно положительные изометричные или слегка вытянутые в широтном направлении локальные аномалии (Булычев и др., 2014). На основании анализа спутниковых данных о гравитационном и аномальном магнитном полях цитируемые авторы разделили Восточно-Индийский хребет на пять участков. Интенсивность локальных магнитных аномалий в каждом участке примерно одинаковая, что позволило им предположить сравнительно одинаковую намагниченность и состав образующих хребет магматических пород. В то же время разная интенсивность локальных гравитационных аномалий свидетельствует о гетерогенности коры, связанной с изменением ее мощности, что обусловлено пространственно-временными вариациями в режиме тектонических, магматических и метаморфических структурообразующих процессов по мере развития хребта. А.А. Булычев с соавторами (2014), будучи сторонниками гипотезы «следа горячей точки», вместе с тем допускают значительный вклад в формировании ВИХ процесса серпентинизации и то, что на разных этапах его развития доминировали разные структурообразующие эндогенные процессы, включая тектоническое скучивание коры и литосферы.

Существенную структурную роль при формировании ВИХ играли сдвиговые смещения, в том числе и в образовании ослабленных зон для проникновения магматического материала после образования хребта (Kopf et al., 2001). По мнению Копфа с соавторами (2001) последняя стадия вулканизма связана с релаксацией напряжений растяжения в ослабленных линеаментах СВ-Ю3 простирания и подъемом магмы вдоль образовавшихся небольших структур пулл-апарт. Эти напряжения могли создавать региональная тектоника и/или источник тепла под хребтом, обусловленный аномальным режимом горячей точки. Ослабленные линеаменты СВ-ЮЗ и СЗ-ЮВ простирания, косо ориентированные относительно главных региональных меридиональных тектонических структур, могли образоваться при левосторонних сдвигах вдоль гигантских разломов типа «Разломной зоны 90 градуса» (Kopf et al., 2001).

Три полигона (П1, П2, П3) 42 рейса НИС «Академик Борис Петров» расположены в древнем северном сегменте ВИХ от $7^{\circ}$ ю.ш. до 5- $7^{\circ}$ с.ш. 
ВЕКЛИЧ и др.

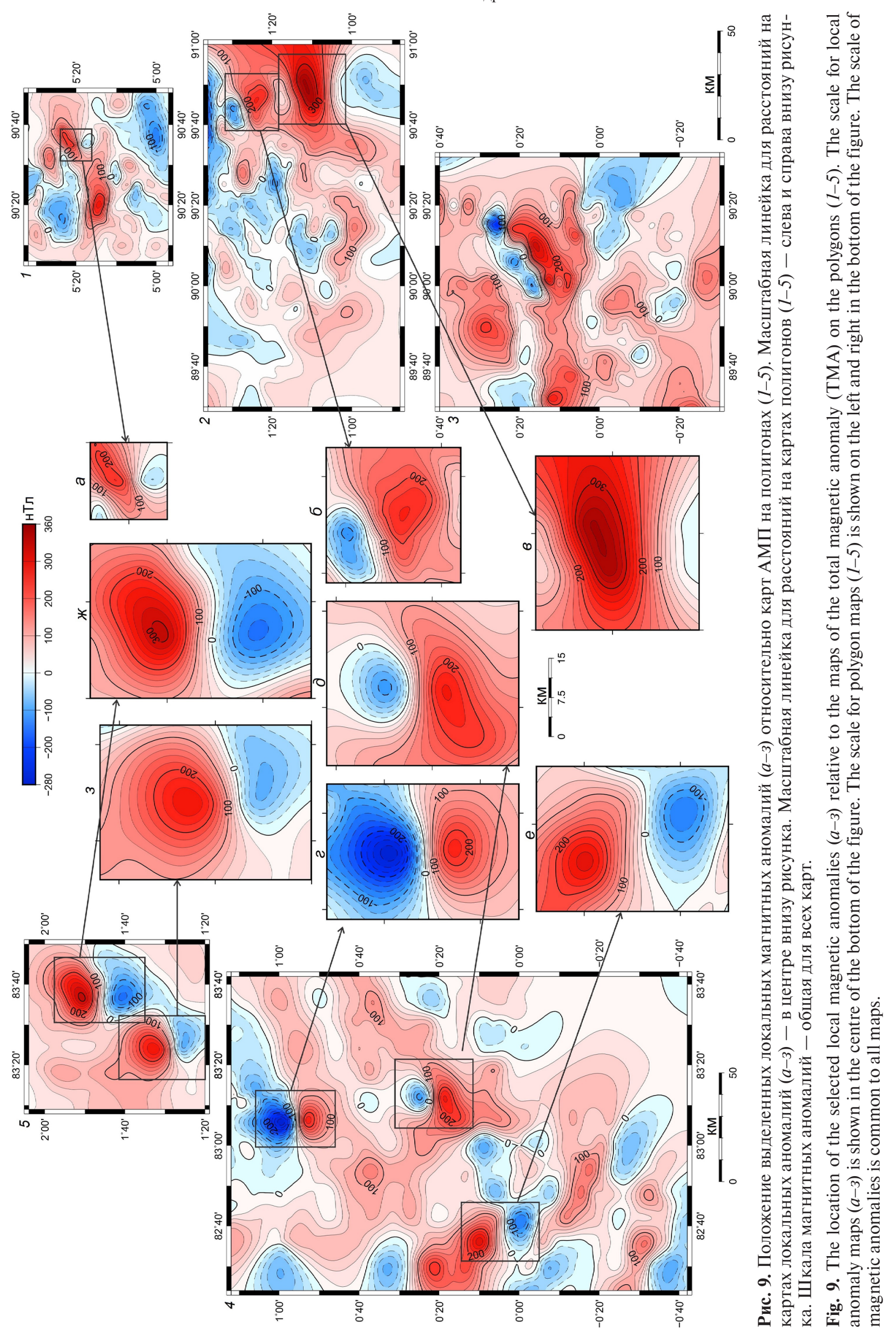




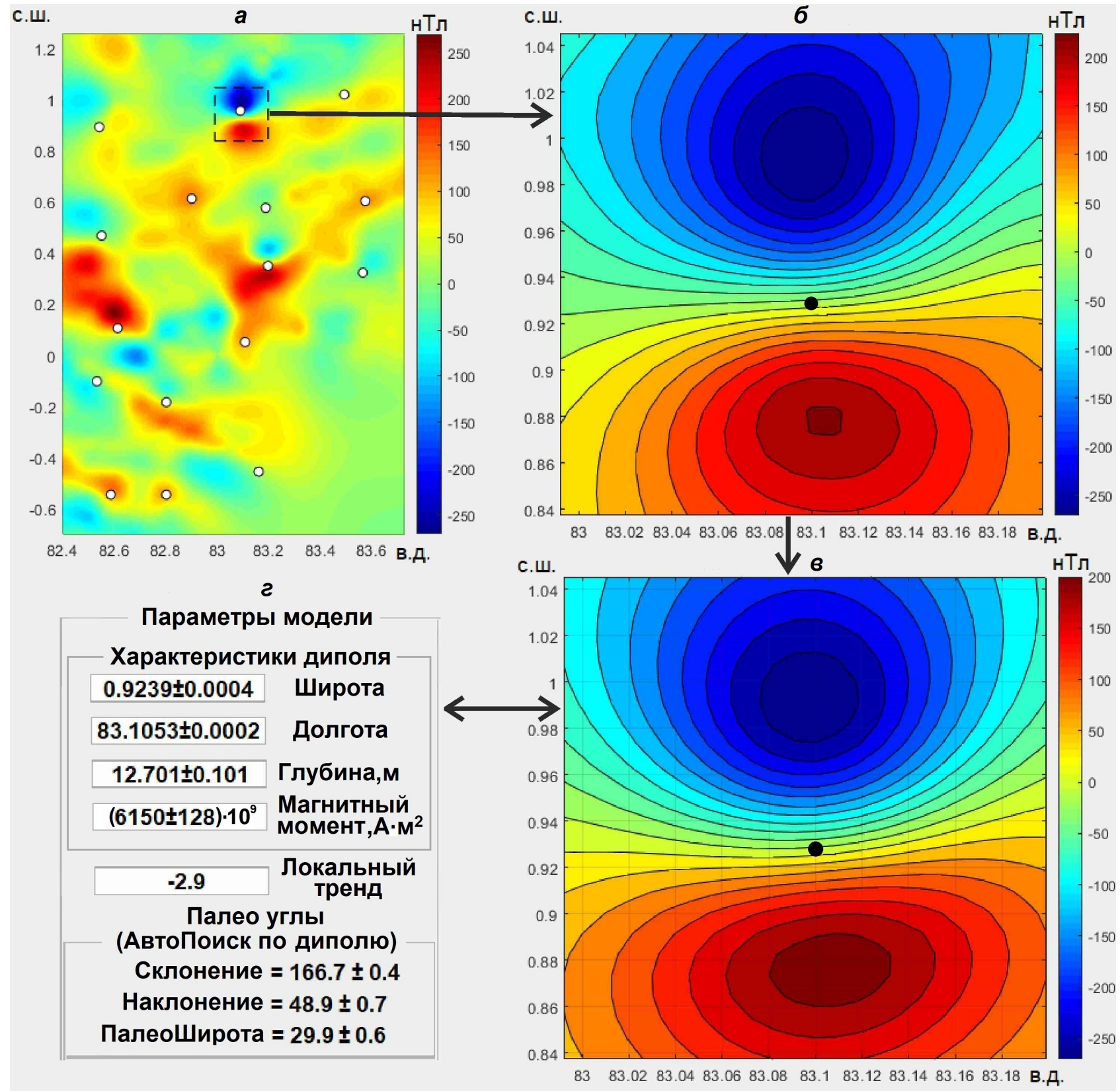

Рис. 10. Пример подбора модели эквивалентного дипольного источника магнитных аномалий на полигоне 4. $a-$ измеренное АМП на полигоне; пунктирная линия оконтуривает фрагмент, использовавшийся при подборе модели; точки маркируют центры источников аномалий, автоматически найденные по магнитуде аномалий. б- фрагмент карты АМП, использованного при подборе модели, точка маркирует центр источника аномалии; в - карта АМП, создаваемого подобранной моделью, точка маркирует положение диполя; г - параметры подобранной модели.

Fig. 10. Example of model selection of equivalent dipole source of magnetic anomalies at polygon 4. $a-$ measured TMA at the polygon, the dashed line outlines its fragment used in model selection, points show the centres of anomaly sources automatically found by anomaly magnitude. $\sigma-$ fragment of the TMA map used in model selection, point show centre of anomaly source; в the map of TMA created using a selected model, a point shows location of dipole; 2- parameters of the selected model.

Морфологически здесь он представляет собой серию эшелонированных массивов, предположительно тектонических блоков, на которые хребет разбит разломами ЮЗ-СВ простирания (Геология ..., 1981; Левченко и др., 2014). Некоторые исследователи рассматривают северный сегмент как особую, специфичную древнюю часть ВИХ, образованную внутриплитным вулканизмом в Индийской плите вдали от спредингового хребта (Левченко и др., 2014; Сущевская и др., 2016; Krishna et al., 2012; Royer et al., 1991). Полигон П1 расположен на южном фланге одного из эшелонированных блоков, полигон П 2 - на юго-восточном фланге соседнего блока, а полигон П3 - 


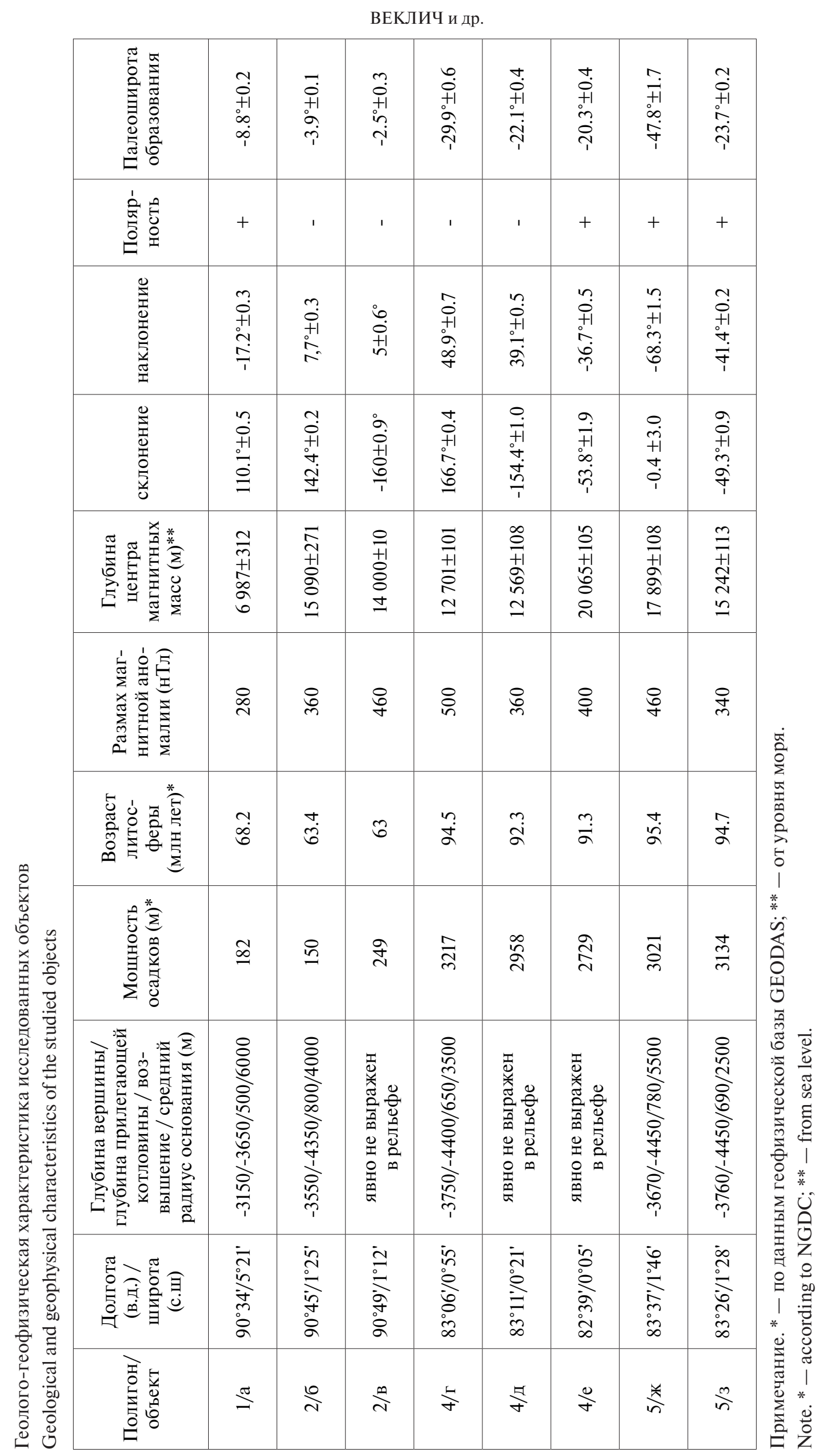


в пределах глубокой поперечной депрессии. Две скважины ODP 758 и DSDP 216 определяют возраст магматических пород этого участка хребта, как 77 и 73 млн лет, соответственно (Krishna et al., 2012). Полигоны П1 (скв. 758) и П2 (скв. 216) совпадают с полигонами рейса НИС «Роджер Ревелл» (2007 г.) (Левченко и др., 2014). Данные геомагнитной съемки, полученные в рейсе НИС «Роджер Ревелл» использованы нами в полном объеме и ранее не публиковались.

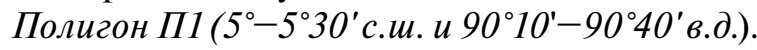
Основные морфоструктуры на полигоне П1 две подводные горы, которые объединены единым цоколем по изобате 3000 м, севернее которых находится скв. 758 (рис. 2a). Корреляция сейсмопрофилей с результатами бурения скв. 758, показала, что эти горы сложены вулканическими породами (Левченко и др., 2014). Вся ЮЗ часть полигона, где находится это локальное поднятие, расположена в одной из глубоких поперечных депрессий, разделяющих северный сегмент хребта на эшелонированные блоки СВ простирания. По данным эхолотного промера, в рельефе дна выделяются два генеральных структурных простирания СВ-Ю3 (азимут $\left.\sim 60^{\circ}\right)$ и С3-ЮВ $\left(\sim 320^{\circ}\right)$.

Основные морфоструктурные элементы ВИХ находят свое отражение в аномальном магнитном поле полигона П1 в виде значительных (до 350 нТл) знакопеременных локальных аномалий, приуроченных либо к поднятиям в рельефе, либо к бортам линейных структур (рис. 2б). К подводным горам приурочены локальные магнитные аномалии, причем разного знака. Над северной горой расположен интенсивный локальный максимум, что соответствует обратной полярности для приэкваториальных объектов. К южной горе приурочена менее интенсивная аномалия, вызванная источником с прямой полярностью. Таким образом, можно предположить разный возраст образования этих объектов: по крайней мере, их разделяет один хрон магнитной геохронологической шкалы (Magnetic ..., 1996). Подобный характер намагниченности изучаемых объектов существенно затрудняет их палеомагнитный анализ посредством трансформаций магнитных аномалий, поскольку эти объекты близко расположены и поля от них сильно интерферируют. Ранее при интерпретации данных рейса НИС «Роджер Ревелл» также отмечалось небольшое различие в тектонике этих вулканических построек, что могло отражать приуроченность их к разным разломам, по которым изливались вулканиты (Левченко и др., 2014).

Обширный минимум АМП в северной части полигона связан, по-видимому, с глубинными источниками в северном массивном сегменте хребта, выходящем за границы исследованной области, и не может быть однозначно интерпре- тирован по данным нашей полигонной съемки. Наиболее интересными с точки зрения геологотектонического изучения ВИХ являются обнаруженные нами слабо выраженные в рельефе, но создающие интенсивные локальные магнитные аномалии, объекты с оцениваемой глубиной до центра магнитных масс порядка 4-5 км ниже поверхности дна, т.е. в слое 3 стандартной модели магнитоактивного слоя океанической литосферы (Городницкий, Шишкина, 1996). Один из этих объектов - локальное поднятие высотой 500 м в северо-восточной глубокой (>3200м) части полигона, к которому приурочена аномалия 280 нТл. Подбор модели для источника этой аномалии показал, что он имеет палеошироту образования от $7.5^{\circ}$ до $8.5^{\circ}$ ю.ш., а центр магнитных масс расположен на глубине 7 км (рис. $9 a$, таблица). Следовательно, он существенно моложе окружающих структур ВИХ, которые согласно результатам глубоководного бурения и гипотезе «следа горячей точки» образованы магматизмом плюма Кергелен значительно южнее, на 50 (Royer et al., 1991).

Полигон П2( $0^{\circ} 50^{\prime}-1^{\circ} 35^{\prime}$ c.m. и 89 $30^{\prime}-91^{\circ}$ в.д.). Полигон П2, расположен в районе скв. 216, его основную часть занимает свод большого вулканического поднятия с глубинами $<2.5$ км (рис. 3a). Здесь широко развиты тектонические нарушения протяженностью в десятки километров, выраженные в рельефе дна и осадочном чехле, простирание которых разворачивается от С3 на севере до ЗС3 и широтного в центре и на юге полигона (Левченко и др., 2014). На востоке он захватывает крутой склон ВИХ, который ступенчато сбросовым уступом высотой от нескольких сотен метров до 1 км погружается в прилегающую котловину Вартон с глубинами >4-4.5 км (рис. 1). На бровке этого восточного склона наблюдается симметричная возвышенность высотой 800 м и 7-8 км в диаметре с довольно крутыми склонами, вероятно, частично тектоническими эскарпами. Возможно, это молодой вулкан или серпентинитовая протрузия (Левченко и др., 2014). Наличие серпентинитов в основании хребта и возможность их влияния на тектонические процессы предполагалось ранее (Булычев и др., 2014; Кашинцев и др., 2000). Магнитные аномалии позволяют оценивать глубинное строение океанической литосферы, вплоть до границы изотермы Кюри, т.е. фактически до границы мантии. Сообщается о возможном вкладе в наблюдаемые аномалии источников в нижних слоях литосферы за счет серпентинизированных и средне-температурно измененных пород в 3 и 4 слоях океанической литосферы (Городницкий, Шишкина, 1996). Используя этот подход можно рассмотреть вопрос, имеют ли место подобные процессы в зоне ВИХ и других структурах Индийского океана. 
Магнитное поле на полигоне П2 представлено преимущественно мозаикой знакопеременных аномалий и в целом демонстрируют преобладание CВ-Ю3 простираний (рис. 3б). Существенной особенностью аномального магнитного поля является преобладание слабо аномального отрицательного мозаичного поля над массивом собственно ВИХ и наличие локальных интенсивных (до 500 нТл) знакопеременных аномалий над его восточным склоном и прилегающим участком котловины. Одна из аномалий с размахом $\sim 360$ нТл приурочена к упомянутой возвышенности на бровке восточного склона хребта. Другая аномалия 460 нТл не коррелирует с рельефом дна, она находится в плоской части глубоководной ( 4500 м) котловины. Выделенные источники аномалий на полигоне П2 имеют относительно близкую к их современному положению палеошироту образования (от $2.5^{\circ}$ до $4^{\circ}$ ю.ш) (рис. 9б, 9в, таблица). Оценка глубины до центра магнитных масс этих объектов показала, что они находятся на больших глубинах от 14 до 15 км.

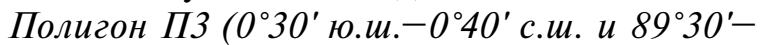
$90^{\circ} 30^{\prime}$ в.д.). Полигон П3 расположен в пределах одной из глубоких поперечных депрессий СВ простирания, разбивающих северный сегмент ВИХ на серию эшелонированных блоков (рис. 1). В структурном плане это участок, где восточная часть хребта обрывается по крупным линейным уступам СВ и ЮЗ простирания, вероятно разломам достаточно глубокого заложения, образующими некий клин, далеко внедряющийся в систему ВИХ (рис. 4a). Очень крутые обрывы, ограничивающие этот клин, имеют высоту до 1-1.5 км. В восточной части полигона в центре депрессии находится узкая линейная гряда того же СВ-Ю3 простирания шириной 2-3 км и длиной $\sim 30$, возможно сложенная серпентинитами.

Магнитные аномалии на полигоне ПЗ достаточно хорошо отражают основные геолого-тектонические элементы этого участка ВИХ (рис. 4б). С основным телом хребта связаны гладкие, средней интенсивности аномалии; здесь, очевидно, преобладают глубинные источники. В то же время, высокоградиентные интенсивные (до 500 нТл) знакопеременные аномалии приурочены к узкой гряде внутри депрессии в восточной части полигона. Предварительный подбор моделей для источников этих аномалий показал, что они имеют схожую палеошироту образования $\sim 9^{\circ}$ ю.ш. и глубины центров магнитных масс от 8.5 до 12.5 км от уровня моря.

Результаты интерпретации геомагнитной съемки на трех полигонах в северном сегменте ВИХ подтверждает общую тектоническую ситуацию с наличием и часто преобладанием нарушенных разломных зон СВ простирания. Вероятно, характер наблюденного АМП частично обусловлен существовавшим здесь магматизмом. Результаты подбора моделей для ряда магнитоактивных объектов в пределах изученного сегмента хребта, показали, что они могли образоваться от $9^{\circ}$ ю.ш. до $2.5^{\circ}$ ю.ш. Некоторые из них (полигон П2) сформировалась в приэкваториальной зоне, и их дрейф на север не превышал $5^{\circ}$ (рис. 9б, 9в, таблица). С учетом их современного положения и скорости широтного дрейфа Индийской плиты в кайнозое 118 км/ млн лет (Krishna et al., 2012), это свидетельствует об относительно молодом возрасте их образования (менее 5 млн лет). Глубины до центра магнитных масс выделенных источников варьируют в широком диапазоне от 7 до 15 км относительно уровня моря, при этом самые глубокие залегают в основании ВИХ.

Образование магнитоактивных источников, имеющих выраженную связь с локальными положительными формами рельефа мы связываем с наложенным вулканизмом в северной части ВИХ. Образованный вблизи экватора источник (рис. 9в), залегающий на глубинах, сопоставимых с границей кора-мантия и не выраженный в рельефе, вероятно, связан с проходящими здесь процессами серпентинизации.

При обсуждении результатов интерпретации мы не можем не затронуть тему выявленных глубоких источников магнитных аномалий и их соответствии данным о глубине изотермы Кюри в регионе. Для ВИХ надежно установлено наличие мощного (до 21-22 км ниже поверхности дна) разуплотненного корня в верхней мантии (Углов и др., 1999). Температура Кюри в океанических породах сильно варьирует в зависимости от типа минерала-носителя магнитных свойств (от 200 до $>600^{\circ} \mathrm{C}$ ), соответственно меняется и глубина до этой изотермы. При наличии серпентинизации или среднетемпературного окисления, эта граница может опускаться на глубину 20 км и глубже, поэтому определяемые нами глубины не противоречат общепринятым представлениям о температурном режиме древней океанской литосферы. Температурный градиент в океанской литосфере также варьирует в широких пределах (25-40\%км), поэтому максимальная глубина серпентинизации здесь может достигать 24-25 км ниже поверхности дна. Более того, при наличии активной тектоники и возникновении проницаемых для воды зон, температурный градиент существенно уменьшается за счет конвективного теплопереноса. Соответственно, изотерма Кюри может погружаться еще глубже.

Центрально-Индийская котловина. Центральная котловина Индийского океана в геомагнитном отношении изучена лучше ВИХ, хотя в основном также маршрутной съемкой, что позволило выявить две системы линейных магнитных аномалий (Krishna et al., 2012). 
Принципиально новые данные, подтверждающие необычное строение литосферы района, были получены во время первых полигонных исследований, выполненных ранее в рейсах ИО РАН (Непрочнов и др., 1988; Intraplate ..., 1998). Зона внутриплитной деформации литосферы южнее Индостана достаточно хорошо изучена сейсмопрофилированием, что дало возможность определить параметры разломов и складок в коре и морфологию отдельных тектонических блоков (Вержбицкий, Левченко, 2002; Казьмин, Левченко, 1987; Левченко и др., 1999; Intraplate ..., 1998). Полигоны П4 и П5 42 рейса в экваториальной части Центральной котловины (рис. 1) расположены в пределах деформированного тектонического блока в районе $0.5^{\circ}$ с.ш. и $83^{\circ}$ в.д. и совпадают с полигоном 22 рейса НИС «Профессор Штокман» (1989 г.) (Intraplate ..., 1998).

Полигон П4 $\left(0^{\circ} 40^{\prime}\right.$ ю.ш. $-1^{\circ} 10^{\prime}$ с.ш. и $82^{\circ} 25^{\prime}-$ $83^{\circ} 40^{\prime}$ в.д.). На полигоне П4 по морфологии дна выделяются три четких разнородных блока (рис. 5a). Юго-западный блок (А) имеет изометричные очертания возвышенности высотой более 500 м. Ее крутой юго-восточный склон более резко погружается в прилегающую глубоководную область, чем пологий северо-западный. Сейсмоакустический профиль через северный склон данной возвышенности показал наличие серии сбросовых структур (амплитудой в первые десятки метров) и преобладание структур растяжения. Расположенная севернее большая возвышенность четко разделяется на два контрастных блока западный (Б) и восточный (В). Меридионально вытянутый блок Б характеризуется мелкой тектонической раздробленностью с преобладанием структурных форм С3 простирания небольшой амплитуды 50 м. С востока к нему примыкает блок В с совсем другим структурным рисунком, создаваемым серией параллельных гряд высотой от 100 до 300 м СВ простирания. Они имеют асимметричный профиль с пологими юго-восточными и крутыми северо-западными крыльями, которые, по-видимому, являются приразломными складками. Этот блок резко отличается от остальных. Разнородные блоки Б и В сочленяются по древнему трансформному разлому Индира, что установлено предшествующими работами (Вержбицкий, Левченко, 2002; Левченко и др., 1999).

Магнитные аномалии на полигоне П4 характеризуются высокой интенсивностью и неоднородностью (рис. 5б). Преобладают локальные интенсивные знакопеременные аномалии, приуроченные к отдельным морфоструктурным элементам, либо даже не связанные напрямую с особенностями рельефа. В то же время наблюдаются очевидные СВ и С3 тренды в простирании аномалий либо их цепочек. СВ простирание ано- малий преобладает в СВ части полигона (блок В) и представлено двумя мощными линеаментами, совпадающими в плане со складками рельефа (и всей коры согласно (Вержбицкий, Левченко, 2002; Левченко и др., 1999)), а С3 простирание в западной части исследованной области (блоки А и Б). Блоку Б соответствуют отдельные более слабые и менее выраженные аномалии. В то же время, нельзя не отметить, как и в районе ВИХ, наличие высокоинтенсивных (>500 нТл) знакопеременных аномалий, приуроченных к относительно небольшим формам рельефа.

Спектральный анализ магнитных аномалий по всей площади дал усредненную оценку положения верхних и нижних кромок источников аномалий на полигоне. Они оказались довольно глубокими - 7.6 и 25.5 км соответственно (3 и 21 км ниже поверхности дна). Для подтверждения этих результатов было выполнено 3D моделирование трех объектов, характеризующихся знакопеременными, хорошо локализованными дипольными аномалиями (рис. 92-e, таблица). Во всех случаях построены модели со значительной (до 16 км ниже поверхности дна) глубиной залегания центров магнитных масс, подтверждающие средние оценки по спектру поля, т.е. магнитоактивный слой на полигоне П4 продолжается намного глубже пределов стандартной модели магнитоактивного слоя океанической литосферы (до 8 км согласно (Городницкий, Шишкина, 1996)) и распространяется не только на кору, но и на верхи мантии. Рассмотренные объекты, приуроченные к низам коры, устойчиво тяготеют к палеоширотам образования 20-30 аномалии, присущие изометричным источникам.

Полигон П5 $\left(1^{\circ} 25^{\prime}-2^{\circ}\right.$ с.ш. и 83 $10^{\prime}-83^{\circ} 50^{\prime}$ в.д.). Полигон П5 характеризуется абсолютным преобладанием мало амплитудных (<50 м) пологих форм рельефа меридионального простирания (некоторые похожие элементы этого типа присутствуют и в северной части блока В полигона П4) (рис. 6a). На фоне относительно спокойного рельефа дна отчетливо выделяются две небольшие подводные горы высотой 700-800 м. Они создают характерные знакопеременные дипольные аномалии с размахом >300 нТл (рис. 6б, 9жс, 9з), по форме и интенсивности схожие с выделенными ранее аномалиями на полигоне П4 (рис. 9z-e). По результатам проведенной интерпретации с подбором эквивалентных моделей установлено, что источниками аномалий на полигоне П5 являются объекты с глубоким залеганием центра магнитных масс (рис. 9ж, 9з, таблица). Оценки палеоширот у них существенно различны - для северного она составляет $48^{\circ}$ ю.ш., а для южного $\sim 24^{\circ}$ ю.ш., что близко к оценкам палеоширот у схожих объектов на полигоне П4 (рис. 92-e, таблица). 
Столь существенное расхождение в оценках палеоширот близко расположенных объектов, похожих по морфологии и форме магнитных аномалий, мы склонны объяснить искажающим влиянием на эту оценку (для северного объекта), наложенного интенсивного отрицательного линейного минимума поля СВ простирания. Данных выполненной геомагнитной съемки недостаточно для более четкого разделения этих разноплановых аномалий и более корректного подбора направления намагниченности. Южный объект (рис. 93) и подобные ему на полигоне П4 (рис. 92-e), скорее всего, являются застывшими магматическими камерами, ответственными за проявления вулканизма на флангах спредингового хребта. Также известно, что процесс образования т.н. «среднетемпературной намагниченности» проходит на больших глубинах (глубже серпентинитов) и температурах свыше $600^{\circ} \mathrm{C}$ при взаимодействии воды с мантийными породами (Базылев, Силантьев, 2000; Городницкий и др., 2017; Kimball et al., 1985). Поэтому не стоит исключать возможность присутствия подобного феномена и в исследуемой области.

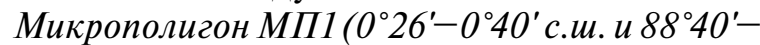
$88^{\circ} 54^{\prime}$ в.д.). Исследования в 42 рейсе НИС «Академик Борис Петров» проводилась также на двух микрополигонах над отдельно стоящими подводными горами. Первая исследованная подводная гора расположена в основании западного склона Восточно-Индийского хребта, на глубине $>4500$ м (рис. 7). Над ней наблюдается интенсивная (>540 нТл) знакопеременная аномалия. Детальная интерпретация всех геофизических данных, полученных на этом микрополигоне, подробно изложена в работе (Левченко и др., 2018), главный вывод из которой заключается в том, что эта гора моложе прилегающих структур основного хребта.

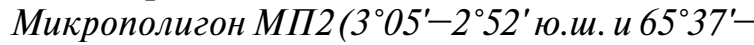
$65^{\circ} 49^{\prime}$ в.д.). Вторая исследованная подводная гора расположена на южном фланге спредингового хребта Карлсберг (рис. 1), на глубине 3900 м. Ее относительная высота 2000 метров, минимальная отметка 910 м (рис. 8a). Изобата 3900 м обрисовывает цоколь этой горы, имеющий форму прямоугольника близкого к квадрату размерами $\sim 15 \times 15$ км (т.е. примерно такие же как и на микрополигоне МП1). К подводной горе приурочена знакопеременная магнитная аномалия с амплитудой >300 нТл сложной формы, указывающая на ее гетерогенное строение (рис. 8б). В результате интерактивного подбора модели по схеме, подобной использованной на микрополигоне МП1 (Левченко и др., 2018), установлено, что основной источник аномалий расположен непосредственно в теле горы и ниже eе, а дополнительный - на ее северном фланге.
Палеоширота образования этих источников лежит в диапазоне от $7^{\circ}$ ю.ш. до $4^{\circ}$ с.ш., что близко к современному положению горы. Это указывает на ее относительно молодой возраст. В целом, для более качественной и точной интерпретации данных по этому объекту необходимы дополнительные исследования.

\section{ЗАКЛЮЧЕНИЕ}

Результаты выполненных исследований подтверждают присутствие современной тектонической активности в северной части ВИХ и зоне внутриплитной деформации. На основе специально разработанной методики, позволяющей рассчитывать положение и направление намагниченности аномальных объектов в экваториальных зонах, получены новые результаты. Оценки палеоширот образования для ряда характерных геологических структур в пределах ВИХ очевидно указывают на возможное развитие здесь наложенных вулкано-магматических процессов, не связанных напрямую с магматизмом горячей точки. Результаты моделирования в зоне внутриплитных деформаций, позволили отнести четыре из 5 исследованных объектов (рис. 92-e, 9з, таблица) к одному типу. Согласно полученным оценкам, данный тип объектов, приуроченный к низам коры, образовался в пределах от $20^{\circ}$ до $30^{\circ}$ ю.ш. что соответствует возрастному интервалу 40-50 млн лет. Мы связываем эти источники с возможными застывшими магматическими камерами, ответственными за проявления вулканизма на флангах спредингового хребта. Эти выводы требуют убедительных прямых доказательств (драгирование, бурение) и являются основанием для дальнейших детальных геолого-геофизических исследований.

В целом, результаты геофизических исследований 42 рейса НИС «Академик Борис Петров» важны для выяснения процессов формирования и эволюции бассейна Индийского океана. Глобально они направлены на решение фундаментальной проблемы геологии и тектоники океанов - магматизм, структурообразование и эволюция литосферы внутриплитных областей Мирового океана: формирование поднятий океанского дна (внутриплитный вулканизм) и деформация литосферы в интерьере океанских плит (внутриплитная тектоника

Авторы выражают благодарность сотрудникам ГЕОХИ РАН А.В. Кольцовой и Б.С. Шмелькову, обеспечившим в рейсе сбор батиметрических данных и их предварительную обработку.

Работа выполнена при финансовой поддержке РФФИ (проекты № 18-05-00316 А и № 19-05-00680 A). 


\section{АНОМАЛЬНОЕ МАГНИТНОЕ ПОЛЕ}

Список литературы [References]

Артамонов А.В., Золотарев Б.П. Тектоника и магматизм внутриплитных океанических поднятий и гипотеза «горячих точек» // Геотектоника. 2008. № 1. C. 77-96 [Artamonov A.V., Zolotarev B.P. Tectonics and magmatism of intraplate oceanic rises and the hot-spot hypothesis // Geotectonics. 2008. V. 42. Iss. 1. P. 64-79. https://doi.org/10.1007/s11479008-1006-z].

Базылев Б.А., Силантьев С.А. Геодинамическая интерпретация субсолидусной перекристаллизации мантийных шпинелевых перидотитов. Срединно-Океанические хребты // Петрология. 2000. T. 8 № 3. C. 227-240 [Bazylev B.A., Silantev $S . A$. Geodynamic interpretation of subsolidus recrystallization of mantle spinel peridotites. MidOcean ridges // Petrologiya, 2000. V. 8. № 3. P. 227-240 (in Russian)].

Булычев А.А., Гилод Д.А., Дубинин Е.П. Гетерогенное строение литосферы восточной части Индийского океана по результатам анализа гравитационного и аномального магнитного полей // Вестник КРАУНЦ. Науки о Земле. 2014. № 2. Вып. 24. C. 41-54 [Bulychev A.A., Gilod D.F., Dubinin E.P. Heterogeneous structure of the lithosphere in the eastern part of the Indian ocean based on the results from the analysis of the gravity and anomalous magnetic fields // Vestnik KRAUNTs. Nauki o Zemle. 2014. № 2(24). P. 41-54 (in Russian)].

Вержбицкий B.E., Левченко O.В. Детальная структура области внутриплитных деформаций в Центральной котловине Индийского океана (результаты исследований на трех полигонах) // Геотектоника. 2002. № 6. C. 77-94 [Verzhbitsky V.E., Levchenko O.V. Detailed Structure of Intraplate Deformation Zone in the Central Indian Ocean Basin (as Deduced from Three Continuous Profiling Sites) // Geotectonics. 2002. V. 36. № 6. P. 498-513].

Геология и геофизика дна восточной части Индийского океана / Под ред. Безрукова П.Л., Непрочнова Ю.П. М.: Наука, 1981. 256 с. [Geology and Geophysics of the Bottom of Eastern Part of the Indian Ocean, Ed. By Bezrukov P.L., Neprochnov Yu.P. Moscow: Nauka, 1981. 256 p. (in Russian)].

Городницкий А.М., Брусиловский Ю.В., Иваненко А.Н. $u \partial p$. Гидратация океанической литосферы и магнитное поле океана // Геофизические исследования. 2017. Т. 18. № 4. С. 32-49. https://doi. org/10.21455/gr2017.4-3 [Gorodnitsky A.M., Brusilovsky Yu.V., Ivanenko A.N. et al. Hydration of the lithosphere and oceanic magnetic field // Geophysical Research. 2017. V. 18. № 4. P. 32-49].

Городницкий A.M., Шишкина Н.А. Обобщенная петромагнитная модель океанской литосферы // Природа магнитных аномалий и строение океанической коры. М.:ВНИРО, 1996. С. 243-252 [Gorodnitsky A.M., Shishkina N.A. Generalized petromagnetic model of the ocean lithosphere // Nature of magnetic anomalies and structure of the oceanic crust. Moscow: VNIRO, 1996. P. 243-252 (in Russian)].

Иваненко A.H. Моделирование магнитного поля подводных гор // Магнитное поле океана / Под ред. Городницкого А.М. М. Наука, 1993. С. 68-88 [Ivanenko A.N. Modeling of the magnetic field of seamounts // Magnetic field of the ocean / Ed. by Gorodnitsky A.M. Moscow: Nauka, 1993. P. 68-88 (in Russian)]

Казьмин В.Г., Левченко О.В. Современные деформации индоокеанской литосферы // Современная тектоническая активность Земли и сейсмичность. М.: Наука, 1987. С. 159-175 [Kazmin V.G., Levchenko O.V. Modern deformations of the Indian Ocean lithosphere // Modern tectonic activity of the Earth and seismicity. Moscow: Nauka, 1987. P. 159-175 (in Russian)].

Кашинцев Г.Л., Непрочнов Ю.П., Гринько Б.Н. Генезис и эволюция Восточно-Индийского хребта // Океанология. 2000. Т. 40. № 6. C. 901-906 [Kashintsev G.L., Neprochnov Yu.P., Grin'ko B.N. The origin and evolution of the Ninetyeast ridge // Oceanology. 2000. V. 40. Iss. 6. P. 850-855].

Кашиниев Г.Л. Аспекты магматизма Восточно-Индийского хребта // Океанология. 2001. Т. 41. № 3. C. 431-436 [Kashintsev G.L. Aspects of magmatism of the Ninetyeast Ridge // Oceanology. 2001. V. 41. Iss. 3. P. 413-418].

Левченко О.В., Евсюков Ю.Д., Милановский В.Е. Детальные исследования морфологии внутриплитных деформаций в Центральной котловине Индийского океана // Океанология. 1999. Т. 39. № 1. C. 121-132 [Levchenko O.V., Evsyukov Yu.D., Milanovskii V.E. Detailed studies in the morphology of intraplate deformations in the Mid-Indian basin of the Indian ocean // Oceanology. 1999. V. 39. Iss. 1. P. 109-119].

Левченко О.В., Сборщиков И.М., Маринова Ю.Г. Тектоника хребта Девяностого градуса // Океанология. 2014. T. 54. № 2. С. 252-266. https://doi.org/10.7868/ S0030157414020142 [Levchenko O.V., Sborshchikov I.M., Marinova Y.G. Tectonics of the NinetyEast Ridge // Oceanology. 2014. V. 54. Iss. 2. P. 231-244. https:// doi.org/10.1134/S0001437014020143].

Левченко О.В., Ананьев Р.А., Веклич И.А. идр. Комплексные исследования подводной горы в основании северного сегмента Восточно-Индийского хребта // Вестник КРАУНЦ. Науки о Земле. 2018. № 3. Вып. 39. С. 90-104. https://doi.org/10.31431/18165524-2018-3-39-90-104 [Levchenko O.V., Ananiev R.A., Veklich I.A. et al. Complex investigation of the seamount at the bottom of the northern part of the Ninety East ridge // Vestnik KRAUNTs. Nauki o Zemle. 2018. № 3(39). P. 90-104 (in Russian)].

Левченко О.В., Шаповалов С.М. Возвращение российских океанологов в Индийский океан: мультидисциплинарные исследования в 42-м рейсе научно-исследовательского судна «Академик Борис Петров» // Океанология. 2019. Т. 59. № 1. C. 181-183. https://doi.org/10.31857/S00301574591181-183 [Levchenko O.V., Shapovalov S.M. Return of Russian oceanographers to the Indian Ocean: multidisciplinary study during the 42nd cruise of the research vessel AkademikBoris Petrov // Oceanology. 2019. V. 59. Iss. 1. P. 164-166. https://doi.org/10.1134/ S0001437019010090].

Непрочнов Ю.П., Левченко О.В., Городницкий А.М. и др. Детальная геофизическая съемка области текто- 
нических деформаций в Центрально-Индийской котловине // ДАН. 1988. Т. 298. № 4. С. 939-944 [Neprochnov Yu.P., Levchenko O.V., Gorodnitsky A.M. et al. Detailed geophysical survey of the area of tectonic deformations in the Central Indian Basin // Doklady Academy of Science. 1988. V. 298. № 4. P. 939-944].

Пущаровский Ю.М. Крупнейшие линейные тектоновулканические поднятия в океанах // Геотектоника. 2011. № 2. С. 3-16 [Pushcharovsky Yu.M. First-order linear tectonovolcanic ridges in oceans // Geotectonics. 2011. V. 45. Iss. 2. P. 101-112. https:// doi.org/10.1134/S0016852111020051].

Сущевская Н.М., Левченко О.В., Дубинин Е.П., Беляикий Б.В. Восточно-Индийский хребет - магматизм и геодинамика // Геохимия. 2016. № 3. C. 256-277. https://doi.org/10.7868/ S0016752516030067 [Sushchevskaya N.M., Levchenko O.V., Dubinin E.P., Belyatsky B.V. Ninetyeast Ridge: magmatism and geodynamics // Geochemistry International. 2016. V. 54. Iss. 3. P. 237-256. https:// doi.org/10.1134/S001670291603006X].

Сущевская H.М., Беляикий Б.В., Дубинин Е.П., Левченко О.В. Эволюция плюма Кергелен и его влияние на магматизм континентальных и океанических областей Восточной Антарктики // Геохимия. 2017. № 9. С. 782-799. https://doi. org/10.7868/S0016752517090096 [Sushchevskaya N.M., Belyatsky B.V., Dubinin E.P., Levchenko O.V. Evolution of the Kerguelen Plume and its impact upon the continental and oceanic magmatism of East Antarctica // Geochemistry International. 2017. V. 55. Iss. 9. P. 775-791. https://doi.org/10.1134/ S0016702917090099].

Углов Б.Д., Зорина Ю.Г., Кабан М.К. Геолого-геофизический атлас Анголо-Бразильского и Маскаренско-Австралийского трансокеанских геотраверзов. М.: ЦНИГРИ, 1999. 24 с. [Uglov B.D., Zorina Yu.G., Kaban M.K. Geological-Geophysical Atlas of the Angola-Brazilian and Mascarene-Australian transocean geotransects. Moscow: TSNIGRI, 1999. 24 p. (in Russian)].

Хаин B.E. Тектоника континентов и океанов (год 2000). М.: Научный мир, 2001. 606 с. [Khain V. E. Tectonics of continents and oceans (year 2000). Moscow: Nauchnyy mir, 2001. 606 p. (in Russian)].

Шрейдер A.A. Геомагнитные исследования Индийского океана. М.: Наука, 2001. 319 с. [Schrader A.A. Geomagnetic studies of the Indian Ocean. M.: Nauka, 2001. 319 p. (in Russian)].

National Geophysical Data Center (NGDC), https://www. ngdc.noaa.gov/.

GEBCO (General Bathymetric Chart of the Oceans). The GEBCO_2014 Grid, version 20150318. http://www. gebco.net.
Delescluse M., Chamot-Rooke N. Instantaneous deformation and kinematics of the India-Australia Plate // Geophysical Journal International. 2007. V. 168. P. 818-842. https://doi.org/10.1111/j.1365246X.2006.03181.x.

Gerovska D., Arauzo-Bravo M.J. Calculation of magnitude magnetic transforms with high centricity and low dependence on the magnetization vector direction. Geophysics. 2006. V. 71. № 5. P. 121-130. https://doi. org/10.1190/1.2335516.

Intraplate deformation in the Central Indian Ocean Basin / Neprochnov Yu. P., Gopala Rao D., Subramaniyam C. et al. Bangalore: Geological society of India. 1998. $250 \mathrm{p}$.

Iyer S.D., Das P., Kalang.tkar N.G. Seamounts - windows of opportunities and the Indian scenario // Current Science. 2012. V. 102. № 10. P. 1382-1391.

Kent D.V., Gradstein F.M. A CRETACEOUS and Jurassic geochronology // Bull. Geol. Soc. Amer. V. 96. № 11. P. 1419-1427.

Kimball K.L., Spear F.S., Dick H.J.B. High-temperature alteration of abyssal ultramafic rocks from the Islas Orcadas fracture zone, South Atlantic // Contributions to Mineralogy and Petrology. 1985. V. 94. P. 307-320.

Kopf A., Klaeschen D., Weinrebe W. et al. Geophysical evidence for late stage magmatism at the central Ninetyeast ridge, Eastern Indian Ocean // Marine Geophysical Research. 2001. V. 22. P. 225-234. https:// doi.org/10.1023/A:1012297315620.

Koppers A.A.P., Watts A.B. Intraplate seamounts as a window into deep earth processes // Oceanography. 2010. V. 23. № 1. P. 42-57. https://doi.org/10.5670/ oceanog.2010.61.

Krishna K.S., Abraham H., Sager W.W. et al. Tectonics of the Ninetyeast Ridge derived from spreading records in adjacent ocean basins and age constraints of the ridge // JGR. 2012. V. 117. B04101. https://doi. org/10.1029/2011JB008805.

Magnetic stratigraphy / Edited by Neil D. Opdyke, James E.T. Channell. Elsevier, Academic Press. 1996. V. 64. P. 341.

Royer J.-Y., Peirce J.W., Weissel J.K. Tectonic constraints on the hot-spot formation of Ninetyeast Ridge // Proccidings Oceanic Drilling Programm Scientific Results. 1991. V. 121. P. 763-776. https://doi. org/10.2973/odp.proc.sr.121.122.1991.

Royer J.-Y., Sandwell D.T. Evolution of the Eastern Indian Ocean since the late Cretaceous: Constraints from Geosat altimetry // JGR.1989. V. 94. № B10. P. $13755-$ 13782. https://doi.org/10.1029/JB094iB10p13755.

Weissel J.K., Anderson R.N., Geller C.A. Deformation of the Indo-Australian plate // Nature. 1980. V. 287. P. 284-291. https://doi.org/10.1038/287284a0. 


\title{
ANOMALOUS MAGNETIC FIELD $\triangle$ Ta IN THE EQUATORIAL INDIAN OCEAN (SURVEY AT POLYGONS)
}

\author{
I.A. Veklich, A.N. Ivanenko, O.V. Levchenko \\ Shirshov Institute of Oceanology, Russian Academy of Sciences, Moscow, Russia, 117997
}

\begin{abstract}
After a long break, during the $42^{\text {nd }}$ cruise of $R / V$ «Academic Boris Petrov» (2017), the Shirshov Institute of Oceanology RAS has resumed full-scale geophysical research in the Indian Ocean. Along with bathymetric and seismoacoustic surveys, the cruise resulted in more than $10000 \mathrm{~km}$ of profiles obtained during the modular hydro-magnetic survey. The main works were performed in the eastern equatorial part of the Indian Ocean, on the Northern segment of the Ninety East Ridge and in the zone of intraplate deformations in the central basin. Special algorithms have been developed for interpreting magnetic anomalies in low latitudes. A number of local intense magnetic anomalies have been detected on the polygons, for which equivalent source models have been developed. These models characterize the associated geological features. Estimations of paleolatitudes for a number of sites in the northern part of the Ninety East Ridge indicate the possible development of superimposed volcanic-magmatic processes here, which are not directly related to the magmatism of the Kerguelen hotspot. The study of intraplate deformations showed that the magnetic layer goes much deeper than the limits of the standard magnetic layer model of the oceanic lithosphere, and the studied objects are probably associated with cooled magmatic chambers formed on the flanks of the spreading ridge.
\end{abstract}

Keywords: Indian Ocean, anomalous magnetic field, tectonics, intraplate deformation. 